\title{
The Effect of Social Media Marketing Activities of E-Commerce Companies on Vocational School of Higher Education Students
}

\author{
Çevik T. ${ }^{1}$ \\ 1 Tuğçe ÇEViK, İstanbul Aydin University, (Turkey) \\ e-mail: tugcecevik@aydin.edu.tr
}

\begin{abstract}
Having a substantial role in our lives thanks to the developments in communication technologies, the concept of social media ranks among the marketing strategies that businesses cannot give up. Social media platforms, playing a large part in institutions' communication and interactions with the target groups, give firms a lot of opportunities to achieve many marketing goals like increasing brand awareness or providing commitment of the target group. Furthermore, the widespread use of the internet has enabled e-commerce sites to be preferred more and the environment provided by social media marketing to e-commerce sites has allowed more transparent mutual communication opportunity in the dialogues between the institution and its target groups. Thanks to these opportunities, target groups have had amenities such as asking questions and giving positive or negative feedback, which cannot be supplied by many other marketing activities. Therefore, the aim of this study is to reveal how the university students, as being young consumers using ecommerce sites, are affected by the marketing activities of these sites on social media.
\end{abstract}

Keywords: Social Media, Social Media Marketing, Integrated Marketing Communication.

\section{Introduction}

Today, along with the changes and transformations in the fields of technology and communication in the global markets, differences in the knowledge of individuals have started to take place. As the diversity of the products and services produced by enterprises increase, consumers become more conscious in response to this, and consequently, there have been differences in the purchasing decision processes of individuals who can obtain information from many places and whose demands, needs and expectations increase in parallel. Besides, instead of traditional marketing strategies, consumers find marketing strategies more attractive in new communication environments and are moving towards these strategies. Because new marketing communication elements make consumers feel special and businesses connect consumers with the specific strategies they offer.

The proliferation of communication channels has forced businesses to adapt their marketing strategies according to these new communication environments. Because the advances in technology have made communication environments that are bi-directional and interactive in the sense of communication indispensable and consumers have now opted out of the passive role in their purchasing decisions, choosing applications where they can express themselves, interact, share ideas, thoughts, wishes and experiences. Social media, which is one of these new communication environments, not only changed the way businesses communicate with their target audiences, but also created significant changes in their marketing strategies. Because social media platforms are more cost-effective than traditional marketing tools and allow businesses to communicate directly with their loyal customers and potential consumers without any time constraints.

The existence of social media in our lives in such a large scale has revealed the necessity of the electronic commerce sites, which carry out marketing strategies on online platforms, to involve themselves in this process. Mostly based on visuals, electronic commerce sites combine social media and e-commerce with ads, campaigns, and carefully managed accounts. On the other hand, it is a fact that e-commerce sites that do not use these platforms, which are highly effective in terms of reaching broad target audiences, increasing brand, product and service recognition, providing consumer support services and interacting with users more by sharing content, will decline in the long term. 


\section{Literature}

Owing to the continuous technological developments in the globalizing world, enterprises have entered into a rivalry competition with each other, and with the development and rapid expansion of technological opportunities, the world has become a global market. In parallel, all commercial activities are also changing. The rapid spread of the internet all over the world has brought about the concept of e-commerce.

As it is known, the word trade is conceptually the name given to process of "buying and selling of goods, services etc." (url 1, tdk.gov.tr). The fact that these transactions are carried out in electronic environment, on the internet, has led to the emergence of the concept of e-commerce. According to the World Trade Organization (WTO), e-commerce is production, advertising, sales and distribution of goods and services through telecommunication networks (url 2, wto.org), and according to the definition of Organization for Economic Cooperation and Development (OECD), an e-commerce is the operation of all kinds of transactions related to commercial activities that concern both enterprises and individuals through computer networks (url 3, oecd.org). In general, electronic commerce is the process of purchasing and selling information, products or services through computer networks, as well as creating demand (marketing), providing customer support (at all stages of sales) for the information, product or service offered, and providing commercial and logistic communication between commercial institutions and their customers through global computer networks (Elibol \& Kesici, 2004: 4).

In order for a commercial activity to be considered as electronic commerce, it is to be conducted in electronic environment, the purchase and sale of products and services must be made between two or more parties, there must be processing and storage of digital information such as text, voice or visual, it must have an economic value and be a commercial transaction and/or support a commercial transaction (Zerenler, 2013: 62). In this context, e-commerce has four perspectives as follows (Iyiler, 2015: 87):

Communication Perspective: Delivery of information, products, services and payments via electronic means,

Business Process Perspective: Usage of technology for automation of business transactions and workflow,

Service Perspective: Cutting costs by increasing the speed and quality of service delivery,

Online Perspective: Online buying and selling of products and information.

E-commerce, which enables the sale, payment, advertisement, customer support and delivery processes of all kinds of products and services securely over the internet, connects vendors, suppliers, dealers and customers with internet and web channels wherever they are in the world.

Electronic commerce tools which are considered as all kinds of technological products that facilitate the commercial activities of enterprises and individuals who trade with each other are computer, internet, mobile phones, telephone, electronic data interchange (EDI), television, electronic payment systems, extranet, intranet and fax. Some of these tools were used for making e-commerce in the periods when technology was not developed (Doganlar, 2016: 4).

E-commerce is not actually a new concept. However, with the development of technology and the widespread use of the internet, it has become one of the most important actors in commercial life. The widespread and professional use of e-commerce began in 1995, and in its early years, it was mainly used in internet-related activities, information technology businesses, and online transactions between large companies, banks and other financial institutions. This period, which is also known as the first period of electronic commerce where web pages are advertised intensively, ends with the decrease in the stock market values of dot-com companies in March 2000, and the second period starts with the re-evaluation of electronic commerce companies in January 2001 (PIrnar, 2005: 32-33). Nowadays, with the widespread use of internet owing to its favorable price, the increase in credit card usage and the innovations in the banking system, all businesses are trying to reduce their costs by spreading e-commerce. 
E-commerce, which brings buyers and sellers together electronically and increases the limits of electronic commerce from national level to international level, is divided into six different groups, considering only the participants (Kalayci, 2008: 142):

- E-commerce between businesses (Business to Business-B2B)

- E-commerce between businesses and consumers (Business to Consumer-B2C)

- E-commerce between businesses and public administration (Business to Goverment-B2G)

- E-commerce between consumers and public administration (Consumer to Government-C2G)

- E-commerce between consumers (Consumer to Consumer-C2C)

- E-commerce between governments (Government to Goverment-G2G)

Among these groups, the most commonly used are; e-commerce between businesses (B2B), ecommerce between businesses and consumers (B2C), and e-commerce between consumers (C2C).

E-commerce between businesses (B2B): The e-commerce model where business is conducted between companies. In this model, both parties sell products and services to one another as businesses. In other words, the companies place orders and make sales in electronic environment to the supplier/manufacturer. Ex: Alibaba.com.

E-commerce between businesses and consumers (B2C): It is the most common and used form of e-commerce in the world. Businesses sell products and services directly to consumers. Thus, there is an opportunity to reach a wide customer base. In this model, businesses can sell a wide range of products and services such as computer, car, book, food and beverage, banking, insurance and stock exchange directly to their customers through virtual store applications. Ex: Amazon.com, hepsiburada.com, n11.com, ebebek.com, idefix.com.

E-commerce between consumers (C2C): This includes the purchases made through the websites with the membership systems where consumers can trade with each other. Ex: ebay.com, gittigidiyor.com, letgo, dolap, gardrops, modacruz.

Internet is now considered to be the most effective tool for e-commerce and internet-based marketing activities have been used extensively in the last 10-15 years. Therefore, it is almost impossible to find a process that cannot be done over the internet. The Internet includes a wide range of activities such as banking transactions, shopping, ordering food, selling second-hand products. For this reason, many businesses engaged in traditional trade have also started to move towards ecommerce activities, and e-commerce, which started with websites, is now being made through these channels due to the inaccessible power of social media channels. Social media, which has become the focal point of our lives with the developing technology with each passing day, is being used effectively by many people and institutions as an online network where the user publishes and shares the content produced individually. In this way, quick access is facilitated and users can view contents, products and services, news, thoughts, daily events and photos through social media and share their views with these social networking platforms.

As one of the most important formations of the 21 st century, social media, as a term, represents the whole of tools, services and applications that enable users to interact using network technologies (Boyd, 2008: 92). Social media platforms are online platforms that provide a natural, intimate conversation environment based on the common interests of the participants based on their ideas and experiences. Its basis is the sharing and integration of the participants at a common point, and often allowing more information to make better choices (Evans, 2008: 31). While, according to Kalafatoğlu, social media is an online communication channel in which people participate, which can be developed and which allows interaction; according to Weber, they're online tools in which people of common interest share their thoughts, comments and ideas; and according to Goeldner and Ritchie, social media platforms are online content areas created by internet users and accessible to other users through interactive technology, and according to Hatipoğlu, it is defined as internet platforms where people carry out their communication activities through text, picture, video and audio files (Buluk \& Eşitti \& Boz, 2017: 220-221). When the definitions of social media, which have many definitions from their tools to functions, content to technological infrastructure, are examined in the literature, it is seen that essentially the interaction and functional characteristics of social media in general are discussed. 
Social media combines technology, social entrepreneurship with words, pictures, videos and audio files, and while the meaning and scope of social media tools change from person to person, the main elements supported by tools such as computers or mobile phones are encountered in various formats such as blogs, microblogs, online chat, RSS feeds, social networks, social bookmarking sites, forums, podcasts, video sharing sites, virtual worlds (Demir, 2016: 28). In this context, in order for an application or website to be suitable for this definition, it must have users independent of the publisher, have content prepared by the users, be unlimited in terms of time and space and users must interact with each other (Erkul, 2009: 3).

According to the We Are Social 2018 report published by We Are Social and Hootsuite, which includes internet usage and social media statistics in the world, when the global internet usage statistics are analysed, the total number of users is 4.02 billion and the number of mobile internet users is 3.72 billion. This ratio shows that almost half of the world's internet users are mobile users. According to the 2017 social media statistics data, there are 3.02 billion social media users in the world, and this number has reached 3.2 billion in the 2018 social media statistics and $42 \%$ of the world's population is social media users and the number of mobile social media users has reached 2.9 billion (url 4, dijilopedi.com). Social media, which is a new form of media that allows the sharing and access of information generated by individuals in a simple, instant and bilateral way, continues to develop rapidly and spreads rapidly by adding new features to itself. Through many platforms such as Instagram, Facebook and Twitter, individuals communicate worldwide and have a strong and effective position when used correctly because there is no boundary and every individual has a voice. With the increasing number of users on social media platforms, the harmonious use of all branches in integrated marketing communication and social media, which is almost a 'hybrid' along with four basic promotion tools, are truly important. Because of this importance, businesses have adapted their marketing strategies to social media usage (Çifci \& Sözen, 2017: 506). Social media tools, which allow individuals freedom and domination compared to traditional media tools, have become an indispensable part of marketing communication today and these platforms, where consumers share their experiences and ideas about the products and services they buy, the brands they prefer and interact with each other, have enabled businesses and brands to communicate more effectively with their target audiences with smaller budgets.

Businesses aim to derive a significant profit by using social media tools in their marketing strategies. These targeted profits include increasing brand awareness and creating positive perceptions, identifying and hiring talented employees, increasing customer satisfaction and customer loyalty, and receiving customer insights in product development and innovation processes (Scott and Jacka, 2011: 36). It is seen that users who devote a large portion of their time to social media platforms, which are rapidly increasing in number every day, collect information about the products and services they are interested in from these platforms, learn and evaluate positive and negative thoughts about brands, and use this information in the purchasing decision processes. Increasing importance of these platforms' day by day for brands and serious investments in these platforms led to the emergence of the concept of marketing through social media.

Social media marketing, which is defined as increasing visibility and promoting goods and services by using social media tools (Güçdemir, 2017: 107), is the process of introducing the pages, products or services created by corporations or consumers on the internet through online channels and interacting with many consumers which are very difficult to reach by traditional advertising methods (Tüten, 2008: 19-20). One of the most important reasons why brands prefer this marketing method is not being able to reach the target audience with traditional marketing strategies or it creates much more cost. However, in social marketing activities, it is possible to reach the right target audience and more people with less budget. Another important reason is that bilateral interaction takes place in a very short time. For example, in case of a negative situation related to a product or service, the consumer conveys this complaint through the brand's social media accounts and the brand resolves the complaint in a short period of time, as well as protecting it from a possible disaster, it also provides convenience and time savings for both parties (url 5, pazarlamaturkiye.com). In order for a marketing activity to be a social media marketing activity, it must have precise and measurable targets, use online social media platforms, and interaction and communication must be bilateral.

The fact that social media marketing has so many alternatives and it has many positive benefits such as facilitating reaching the target audience, causes e-commerce sites to use social media as a marketing tool. Electronic commerce sites are now directing their marketing strategies such as 
communicating and interacting with consumers, observing demands for products and services, creating brand and product awareness through social media platforms.

\section{Research}

Nowadays, social media applications are particularly used by university students who are young individuals. In this context, investigating to what extent the new media channels have gained a place in marketing communication for the students and to what extent university students attach importance to the marketing activities they face while using the internet and social media channels play an important role for businesses in reaching out to young individuals that make up a large part of their target audience and determining their marketing strategies.

The research is important for determining the extent to which the university students, who are a major part of the target audience of e-commerce sites, are affected by the marketing activities of the social media channels of e-commerce sites. Within this scope, the main purpose of the research is to investigate the importance the students studying in public relations and publicity departments of vocational schools of higher education in foundation universities attach to marketing activities of ecommerce sites on social media. In this context, four basic hypotheses were determined to be tested in accordance with the aim of the research and developed as follows:

Hypothesis 1. There are significant differences between the genders in terms of marketing activities of e-commerce sites on social media.

$\mathrm{H} 1$ (a): There are significant differences between the genders in terms of the activity aspect of the marketing activities of e-commerce sites on social media.

$\mathrm{H} 1$ (b): There are significant differences between the genders in terms of the like aspect of the marketing activities of e-commerce sites on social media.

Hypothesis 2. There are significant differences between ages in terms of marketing activities of e-commerce sites on social media.

$\mathrm{H} 2$ (a) There are significant differences between the ages in terms of the activity aspect of the marketing activities of e-commerce sites on social media.

$\mathrm{H} 2$ (b) There are significant differences between ages in terms of the like aspect of the marketing activities of e-commerce sites on social media.

Hypothesis 3 . There is a relationship between the marketing activities of e-commerce sites on social media and the time spent on social media.

$\mathrm{H} 3$ (a) There is a relationship between the time spent on social media in terms of the activity aspect of the marketing activities of e-commerce sites on social media.

$\mathrm{H} 3$ (b) There is a relationship between the time spent on social media in terms of the like aspect of the marketing activities of e-commerce sites on social media.

Hypothesis 4. There are significant differences between the activity and like aspects of marketing activities of the e-commerce website, which is the mostly / most often preferred for shopping, on social media.

Quantitative research method is used in order to reach the findings. Data collection is performed by face to face questionnaire. There are 29 expressions in total together with demographic questions and the survey consists of three main sections. In the first section, four questions measuring demographic data related to the participants, in the second section, 10 expressions designed to examine the participants' internet and social media usage, and in the third section, social media marketing activities (SMMA) scale adapted to Turkish by Yuksekbilgili (2018) in order to measure the marketing activities of e-commerce sites on social media and 15 expressions in this scale and also 7point Likert-type scale are preferred. (1- Strongly Disagree, 2- Disagree, 3- More or Less Disagree, 4Undecided, 5- More or Less Agree, 6- Agree, 7- Strongly Agree). In addition, the names of the 13 ecommerce sites included in the statements in the second section are taken from the research carried out with the participation of 2085 people prepared by Twentify (2018) (url 6, Twentify).

The general population of the study consists of university students. However, due to the difficulty of reaching the entire research population and the time and budget limitations, the study is limited to the sample. Accordingly, the sample of the study consists of a total of 226 associate degree 
students, in formal and evening educations, studying in public relations and publicity programs of vocational schools of higher education in three foundation universities in ìstanbul which are determined by convenience sampling method. Descriptive statistics (mean, standard deviation, minimum, median, maximum) are used to define continuous variables. Comparison of the two variables that are not compatible with independent and normal distribution is made by the MannWhitney $U$ test, and the comparison of more than two variables which are not compatible with independent and normal distribution is made by the Kruskal-Wallis Test, and the comparison of categorical variables is made by the Chi-Square Test. Correlations between two continuous variables that are not suitable for normal distribution are examined by Spearman's Rho Correlation Analysis and analyzed using IBM SPSS Statistics Version 25.0.

As a result of the analysis of the data collected through face-to-face questionnaires among the vocational school students participating in the study, when the distribution of the students studying in the associate degree of public relations and publicity program according to their gender (Table 1) is examined, the majority of the participants are women with $67.7 \%$. When the marital status is examined, it is observed that the majority of the students $(92.5 \%)$ are single and when it is considered in terms of age group, it is observed that $85.8 \%$ of the students are in the 18-24 age group. When the total monthly income of the participants is examined, TL 0-1000 is the income group with the highest number of participants $(48.7 \%)$.

\begin{tabular}{llcc}
\hline & & Frequency & Percent (\%) \\
\hline Gender & Female & 153 & 67.7 \\
& Male & 73 & 32.3 \\
\hline Marital Status & Married & 17 & 7.5 \\
& Single & 209 & 92.5 \\
\hline Age & $18-24$ & 194 & 85.8 \\
& $25-34$ & 23 & 10.2 \\
& $35-44$ & 8 & 3.5 \\
& 45 and over & 1 & 0.5 \\
\hline Monthly Total Income & TL 0-1,000 & 110 & 48.7 \\
& TL 1,001-2,000 & 44 & 19.5 \\
& TL 2,001-3,000 & 26 & 11.5 \\
& TL 3,001-4,000 & 21 & 9.3 \\
& TL 4,001-5,000 & 9 & 4.0 \\
& TL 5,000 and over & 16 & 7.1
\end{tabular}

Table 1. Demographic Features

In Table 2, it is stated whether the students studying in the public relations and publicity associate degree program use internet and social media applications and if so, how many hours they spend on the internet and social media applications per day. In this context, it is seen that all the students who participated in the research use internet and $43.4 \%$ spend time on the internet for 4-7 hours. In addition, it is identified that all but one of the students use social media applications and more than half of the participants (54.9\%) spend at least 3 hours in these mediums. In this context, it is observed that the students spend most of their time on social media applications.

\begin{tabular}{llcc}
\hline & & Frequency & Percent (\%) \\
\hline Using Internet & Yes & 226 & 100 \\
& No & 0 & 0 \\
\hline \multirow{2}{*}{ Daily Internet Usage Times } & Any & 0 & 0 \\
& $0-3$ hours & 89 & 39.4 \\
& $4-7$ hours & 98 & 43.4 \\
& $8-11$ hours & 26 & 11.5 \\
Use of Social Media Applications & More than 12 hours & 13 & 5.8 \\
\hline \multirow{3}{*}{ Daily Social Media Usage Times } & Yes & 225 & 99.6 \\
& No & 1 & 0.4 \\
\hline & Any & 0 & 0 \\
& Table 2. Daily Internet and Social Media Usage Status & 54.9 \\
& 4-7 hours & 124 & 32.7
\end{tabular}


The students who are studying in the public relations and publicity associate degree program were asked which social media application they use most and the distribution of the students' answers to this question is given in Table 3. Among the most preferred social media tools; Instagram, which is used frequently by brands due to its high level of interaction and enabling trade, appears to be in the first place among young people. Brands provide information about their products to consumers through Instagram accounts, make sales, and listen to suggestions and complaints.

\begin{tabular}{lcc}
\hline & Frequency & Percent (\%) \\
\hline Facebook & 19 & 8.4 \\
Twitter & 46 & 20.4 \\
Instagram & 212 & 93.8 \\
Other & 32 & 14.2
\end{tabular}

Table 3. Most Used Social Media Application

The students in the study were asked whether they shop online or not, it was identified that $100 \%$ of the students $(n=226)$ shop online. In addition, the students were asked how often they shop online and the distribution of the answers to this question is given in Table 4. According to Table 4, more than half $(66.4 \%)$ of the participants shop online.

\begin{tabular}{lcc}
\hline & Frequency & Percent (\%) \\
\hline Everyday & 0 & 0 \\
Once a week & 10 & 4.4 \\
2-3 Times per Week & 8 & 3.5 \\
Once in a month & 150 & 66.4 \\
2-3 Times per Month & 58 & 25.7
\end{tabular}

Table 4. Frequency of Online Shopping

In order to determine whether the surveyed students follow the social media accounts of ecommerce sites, they were asked whether they follow Facebook / Twitter / Instagram and other social media accounts of e-commerce sites, and $58 \%(n=131)$ of the participants responded positively and $42 \%(n=95)$ responded negatively.

\begin{tabular}{lcclcc}
\hline & Frequency & Percent (\%) & Frequency & Percent (\%) \\
\hline n11.com & 29 & 12.8 & Aliexpress & 7 & 3.1 \\
Markafoni & 4 & 1.8 & ePttAVM & 0 & 0 \\
morhipo & 5 & 2.2 & Migros Sanal Market & 6 & 2.7 \\
trendyol & 131 & 58.0 & Özdilekteyim & 0 & 0 \\
Lidyana & 2 & 0.9 & Boyner & 4 & 1.8 \\
hepsiburada.com & 18 & 8.0 & sahibinden.com & 11 & 4.9 \\
gittigidiyor.com & 9 & 4.0 & & &
\end{tabular}

Table 5. Distribution of Most Preferred E-Commerce Sites for Shopping

When the e-commerce sites where the students prefer to shop most are analysed, it is observed that more than half $(58 \%)$ of the participants prefer trenyol and $\mathrm{n} 11 . \mathrm{com}(12.8 \%)$. When the data in Table 5 is examined, it is seen that the participants are mostly concentrated in a single e-commerce site. Again in Table 6, it is seen that the students who participated in the survey mostly see the ads of trendyol $(52.7 \%)$ e-commerce website in their social media applications. 


\begin{tabular}{lcclcc}
\hline & Frequency & Percent (\%) & & Frequency & Percent (\%) \\
\hline n11.com & 27 & 11.9 & Aliexpress & 9 & 4.0 \\
Markafoni & 8 & 3.5 & ePttAVM & 0 & 0 \\
morhipo & 6 & 2.7 & Migros Sanal Market & 4 & 1.8 \\
trendyol & 119 & 52.7 & Özdilekteyim & 0 & 0 \\
Lidyana & 1 & 0.4 & Boyner & 11 & 0.9 \\
hepsiburada.com & 25 & 11.1 & sahibinden.com & & 4.9 \\
gittigidiyor.com & 14 & 6.2 & &
\end{tabular}

Table 6. Distribution of E-Commerce Sites with Most Advertisements in Social Media Applications

According to both Tables (Table 5 and Table 6 ), the participants do not see the advertisements of ePttAVM and Ozdilekteyim e-commerce sites in social media applications and prefer not to shop from these sites. The data of the first hypothesis, which is one of the hypotheses based on the research, "There are significant differences between the genders in terms of marketing activities of ecommerce sites on social media," (H1) are shown in Table 7.

\begin{tabular}{lcc|cc|c}
\hline & \multicolumn{2}{c}{ Activity } & \multicolumn{2}{c}{ Like } \\
\hline & Mean & Std. Deviation & Mean & Std. Deviation \\
Female & 41.6 & & 9.6 & 27.7 & 7.5 \\
Male & 41.9 & & 10.3 & 27.5 & 8.4 \\
$\mathrm{P}^{*}$ & & 0.846 & & & 0.767
\end{tabular}

*Mann-Whitney U (0.05 significance level, $p<0.05)$

Table 7. Gender Distribution of E-Commerce Sites in Terms of Marketing Activities in Social Media

When Table 7 is examined, it is found that there is no statistically significant difference in terms of the activity aspect $(p=0.846>0.05)$ and like aspect $(p=0.767>0.05)$ of the marketing activities of e-commerce sites on social media in terms of gender. Hypothesis 1 is rejected according to the conclusion that there is no significant difference in terms of the marketing activities of these sites on social media to reach both male and female students. Considering the relationship between the age of the students in the sample group and the marketing activities of the e-commerce sites on social media, the results of the analysis regarding the hypothesis $\mathrm{H} 2$, "There are significant differences between ages in terms of marketing activities of e-commerce sites on social media," are given in Table 8.

\begin{tabular}{|c|c|c|c|c|}
\hline & \multicolumn{2}{|c|}{ Activity } & \multicolumn{2}{|c|}{ Like } \\
\hline & Mean & Std. Deviation & Mean & Std. Deviation \\
\hline $18-24$ & 41.5 & 9.8 & 27.7 & 7.6 \\
\hline $25-34$ & 43.7 & 10.7 & 27.8 & 8.8 \\
\hline $35-44$ & 43.4 & 8.5 & 27.4 & 10.1 \\
\hline 45 and over & 32 & - & 19 & - \\
\hline$P^{*}$ & \multicolumn{2}{|c|}{0.540} & \multicolumn{2}{|c|}{0.984} \\
\hline
\end{tabular}

Table 8. Age Distribution of E-Commerce Sites in Terms of Marketing Activities in Social Media

Accordingly, it is seen that there is no statistically significant difference in terms of the age of the students participating in the study in terms of the activity aspect $(p=0.540>0.05)$ and like aspect $(p=$ $0.984>0.05$ ) of the marketing activities on social media of e-commerce sites and hypothesis 2 is rejected. According to the analysis made in Table 9 on whether there is a relationship between the time spent on social media and the marketing activities of e-commerce sites in the social media, it is observed that although there is no significant difference in terms of the time the students spend on social media in terms of the activity aspect of the marketing activities of e-commerce sites, there is a statistically significant relationship between the like aspect and the time spent on social media. 


\begin{tabular}{lc|cc|c}
\hline & \multicolumn{3}{c}{ Activity } & \multicolumn{2}{c}{ Like } \\
\hline & Mean & Std. Deviation & Ort. & Std. Deviation \\
Any & - & - & - & - \\
0-3 hours & 41 & 9.6 & 26.2 & 7.9 \\
4-7 hours & 42.6 & 9.3 & 29 & 6.6 \\
8-11 hours & 41.4 & 11.6 & 23.9 & 9.4 \\
more than 12 hours & 48.8 & 10.5 & 34 & 7.3 \\
$\mathrm{P}^{*}$ & & 0.388 & & 0.015
\end{tabular}

\section{Table 9. The Relationship between Marketing Activities of E-Commerce Sites in Social Media and Time Spent on Social Media}

*Kruskal-Wallis $p<0.05{ }^{* *}$ Comparisons were made between 0-3 hours, 4-7 hours and 8-11 hours. Since there were six people in the group with more than 12 hours, they were not included in the comparison.

The most frequently preferred e-commerce site for the students in the study and the marketing activities of these sites on social media are examined and the results of the analysis are shown in Table 10. According to the table, it is identified that there is a high and statistically significant correlation between activity and like aspect in N11 users, there is a good and statistically significant correlation between activity and like aspect in Trendyol users and moderate and statistically significant correlation in Hepsiburada.com users. In this context, it is seen that there are significant differences between the activity and like aspects of the marketing activities of the most preferred e-commerce site for shopping on social media, and Hypothesis 4 is accepted.

\begin{tabular}{lcc}
\hline & $\mathbf{r}^{*}$ & $\mathbf{p}$ \\
\hline n11.com & 0.826 & $<0.001$ \\
Trendyol & 0.666 & $<0.001$ \\
hepsiburada.com & 0.587 & 0.010 \\
*Spearman's Rho Correlation Coefficient &
\end{tabular}

Table 10. Relationship between E-Commerce Sites' Marketing Activities in Social Media and
Most / Most Frequently Preferred E-Commerce Sites for Shopping

\section{Conclusion}

With the development and widespread use of the internet all over the world and in our country, the increasing use of new media shows us that the Internet will take more place in every area of our lives. Developing and changing marketing strategies thanks to social media channels enable all businesses to sell their products and services on social media, and through these channels, businesses interact more quickly with their target audiences. In parallel with this interaction, they have the opportunity to change the perception existing in their target groups about their products and services in a positive or negative way. Therefore, with the feedback they receive from their target groups, businesses can benefit when they correctly understand and direct their consumer's wishes, needs and thoughts about their products and services. In this context, it is essential to ensure that consumers talk and share their products and services in social media.

The fact that consumers share their experiences about a product or service in these channels affects the purchasing decision processes of other consumers. Because the consumer who will buy products or services for the first time now chooses to get information through social media channels. In particular, these social media channels, which are used extensively by young people, are important in terms of marketing strategies of businesses that target young people in these days, where they establish social relations, acquire information, share ideas, thoughts, feelings and wishes, are influenced by the shares made and manage their lives with mobile devices always in their hands. In this respect, it is an undeniable fact that the social media platforms actively used by university students, called young consumers, are also effective in terms of integrated marketing strategies of electronic commerce sites. The study is prepared to measure these effects. Within the scope of the research, it is attempted to determine the perspectives of university students about the marketing activities in the social media channels of the e-commerce sites that they prefer frequently and to what extent these activities affect the students. Accordingly, more than half of the students participating in the study are found to be women. In addition, it is identified that the majority of the students participating in the study are single and between the ages of 18-24 and all of them use the internet. It 
has been observed that all of these individuals who spend at least seven hours a day on the internet use social media applications and spend at least three hours a day on these channels and among the social media channels, young consumers use Instagram the most, which is one of the social sharing sites. Consequently, for e-commerce sites that want to include young consumers who use social media extensively in their marketing strategies, having an Instagram account or advertising this application will lead to positive feedback.

Today, shopping preferences are made over the internet and university students, who are young consumers, use the internet for shopping, which provides a competitive advantage for businesses. Looking at the shopping preferences of the students participating in the study, it is concluded that all of them choose the internet and they shop online at least once a month. These individuals who decide to purchase over the internet often follow the social media accounts of e-commerce sites. In this context, e-commerce sites operating in social media channels should constantly update their accounts and return effectively to their customers' wishes, needs, suggestions and complaints.

According to the study, students generally prefer trendyol and n11.com e-commerce sites while shopping on the internet and they encounter the advertisements of these two e-commerce companies in social media most. Another result of the research is that the students do not see the ads of ePttAVM and Ozdilekteyim sites which are among the e-commerce businesses in social media applications and they do not prefer to shop from these sites. It is found out that the marketing activities of e-commerce sites designed in the scope of the research do not create a change in terms of age and gender, and that the activity part of the marketing activities of e-commerce sites on social media is not effective but the students like these activities. It is studied whether there is a relationship between the e-commerce site that the students in the study prefer most / most frequently for shopping and the marketing activities of these sites on social media, and among the 13 e-commerce sites included in the study, it is seen that $\mathrm{n} 11 . \mathrm{com}$ website is in demand for marketing activities in the social media channels. Accordingly, businesses should choose the social media platform appropriate for their target audiences for their marketing strategies to be established in social media channels, and they should decide which targets they will focus on, such as brand awareness, selling, reselling to old customers, using social media channels only as a communication channel between the brand and the customer, increasing website traffic or increasing their business potential. Also, producing content aimed at the target audience and the brand, and planning content such as publishing at the most active hours of the target audience is important for creating an effective social media marketing strategy.

\section{References}

[1] Boyd, D. M. (2008). American Teen Sociality in Networked Publics. PhD Dissertation. University of California-Berkeley

[2] Buluk, B. \& Eşitti, B. \& Boz, M. (2017). Sosyal Medyanın Kullanım Amaçları: Üniversite Çalışanları Örneği. Eurasia International Research Journal, 5(10), 219-234.

[3] Çifci, S. \& Sözen, D. (2017. Tüketicilerin Sosyal Medya Pazarlama Aktivitelerine Katılımlarının Etkileyicileri ve Sonuçları. Ege Akademik Bakış Dergisi, 17(4), 505-515.

[4] Demir, Ü (2016). Sosyal Medya Kullanımı Ve Aile İletişimi: Çanakkale'de Lise Öğrencileri Üzerine Bir Araştırma. Selçuk Communication Journal, 9(2), 27-50.

[5] Evans, D. (2008). Social Media Marketing an Hour a Day. İndiana: Wiley Publishing.

[6] Elibol, H. \& Kesici, B. (2004). Çağdaş İşletmecilik Açısından Elektronik Ticaret. Selçuk University Social Sciences Journal, 11, 303-329.

[7] Erkul, E. (2009). Sosyal Medya Araçlarının (Web 2.0) Kamu Hizmetleri ve Uygulamalarında Kullanılabilirliği. Turkey Informatics Association Journal, 116, 96-101.

[8] Güçdemir, Y. (2017). Sosyal medya: Halkla ilişkiler, reklam ve pazarlama. İstanbul: Derin Yayınları.

[9] İyiler, Z. (2015). E Ticaret. İstanbul: İstanbul Sanayi Odası Yayınları.

[10] Kalaycı, C. (2008). Effects on Electronic Commerce and SMEs, International Journal of Economics and Administrative Studies, 1/1 (1), summer, 139 - 150.

[11] Pırnar, İ. (2005). Turizm Endüstrisinde E-Ticaret. Economic and Social Research Journal, Fall, 1, 28-55. 
[12] Scott, P. R. \& Jacka, J. M. (2011). Auditing Social Media: A Governance and Risk Guide. New Jersey: John Wiley \& Sons.

[13] Tuten, T. L (2008). Advertising 2.0: Social media marketing in a web 2.0 world. USD: Praeger Pub.

[14] Yüksekbilgili, Z. (2018). Sosyal Medya Pazarlama Aktiviteleri Ölçeğinin Türkçeye Uyarlanması: Güvenilirlik ve Geçerlilik Çalışması, Selçuk Üniversitesi Sosyal Bilimler Meslek Yüksekokulu Dergisi 21(2), Kasım, 149-157.

[15] Zerenler, M. (2013). Dijital İş Yaşamı: Tüm Boyutlarıyla Elektronik Ticaret. Ankara: Gazi Yayınları.

[16] url1- commerce, http://www.tdk.gov.tr/index.php?option=com_bts\&arama=kelime\&guid=TDK.GTS.5ce 3c3aad8d755.22566817, Accessed: 01.04.2019.

[17] url 2 - e-commerce, http://www.wto.org/wto/ecom/e-press96.html, Accessed: $\quad$ 01.04.2019.

[18] url 3 - e-commerce, http://www.oecd.org/ecommerce/, Accessed: 01.04.2019.

[19] url 4 https://dijilopedi.com/2018-internet-kullanimi-ve-sosyal-medya-istatistikleri/, Accessed: 27.04.2019

[20] url 5 - social media marketing, https://pazarlamaturkiye.com/sosyal-medya/sosyalmedya-pazarlamasi-nedir-ornekleri-ve-stratejileri-nelerdir/, Accessed: 27.04.2019.

[21] url 6 - Çevrimiçi Alışverişte Tüketici Davranışları Araştırması ve Marka Karşılaştırması: Türkiye'de E-ticaret Araştırma Raporu, https://www.twentify.com/tr/raporlar/turkiyede-eticaret-cevrimici-alisveriste-tuketici- davranislari-arastirmasi-ve-marka-karsilastirmasi, Accessed: 03.03.2019. 